GLOBAL JOURNAL OF EDUCATIONAL RESEARCH VOL 14, 2015: 101-108 COPYRIGHTC BACHUDO SCIENCE CO. LTD PRINTED IN NIGERIA. ISSN 1596-6224

www.globaljournalseries.com; Info@globaljournalseries.com

\title{
MARKETING DESTINATION INFORMATION IN A TOURISM DRIVEN ECONOMY: THE CROSS RIVER STATE EXAMPLE
}

\section{ERIC OFRE, RUTH SIMON BASSEY AND FIDELIS E. INYOKWE}

(Received 14, November 2014; Revision Accepted 6, February 2015)

\begin{abstract}
This paper studies the destination information marketing as an aid to the Cross River Tourism bid. A questionnaire was designed to elicit responses from the stakeholders in the tourism industry. Out of 69 questionnaire copies administered on tourist and workers in three popular hotels in Calabar (University of Calabar Hotel, Marian hotel and the Transcorp, Calabar) 50 unusable copies were retrieved and used in the analyses. The findings showed a predominance of domestic tourists in Cross River State. The sites/events most frequently visited included Christmas Festival, Obudu Mountain Race, Tinapa Holiday/Business Resort, Obudu Mountain Resort, Marina Resort (Water Front) and Leboku New Yam Festival. The single bedroom accommodation and double rooms are the most preferred accommodations. The most preferred tourist means of transportation included public mass transit, chartered taxis and car hire services. The most popular sources of tourism information in Cross River State were tourist guide books, internet and the Tourism Bureau. The most preferred souvenirs on Cross River State included indigenous art works and utilities. The most frequent complaint of tourists was the bad state of the roads. The most frequent complementary remarks were: "the state is very clean and beautiful", "the people are very friendly"; "the state is very, very peaceful". Suggestions were given for improvement.
\end{abstract}

KEY WORDS: Marketing, destination information, tourism driven economy, Cross River State.

\section{INTRODUCTION}

Tourism, as a travel for recreation, leisure and business has been a part of man's activities since the dawn of civilization. The word tourist was first used in 1772 (The Monthly Review, n.d.) and tourism by 1811(Online Etymological Dictionary, 2013). Nature and beauty are appreciated by all normal human beings in search of fun. What is perhaps new about tourism is the present drive to make it an alternative income earner for states and investment opportunities for investors.

Gee and Fayo-Sola (1997), for instance, who looked at tourism from a global perspective, reported that the travel and tourism industry is the world's largest and most diverse industry. They reported that it is three times bigger than the world's expenditure on defense. The authors observed that many nations rely on this dynamic industry (Nickerson, 1996) as a primary source for generating revenue, employment, private sector growth and infrastructure development. They believe that tourism is encouraged particularly among the developing countries around the world, when other forms of economic development, such as manufacturing or the exploitation of natural resources, are not commercially viable.

The factors for tourism development

Eric Ofre, Head Reference Services Division, University of Calabar Library, Calabar, Nigeria.

Ruth Simon Bassey, University Librarian, University of Calabar, Calabar, Nigeria.

Fidelis E. Inyokwe, Head, Research Library Division, University of Calabar Library Calabar, Nigeria. 
outlined above are akin to those of Cross River State. Recently, so much injustice was visited on the state. The oil-rich Bakassi Peninsula, a property of Cross River State was unjustly and brazenly awarded to Cameroun by the International Court of Justice (ICJ). Not quite long afterwards, as if to add insults to injury, a supposedly sister state successfully claimed 76 oil wells property of Cross River State. These twin evils left the state almost economically wrecked and in shambles.

But rather than weep over spilt milk, the state engaged in public-private partnership assistance from international financial institutions to embark on developing alternatives income opportunities. A tourism master plan was drafted. The tourism policy and practice in Cross River State is captured in the acronym CALABAR, meaning Come and Live and Be At Rest (Cross River State Government, 2010). This applies not only to the city of Calabar, but to the entire state of Cross River State which offers visitors a safe and relaxing atmosphere away from the commotion and congestion of Nigeria's big cities. Recognizing this, the government of Cross River State has made tourism development a priority and is working in tandem with the private sector to brand Cross River State a premier destination for Nigerians and foreigners alike.

Cross River Tourism assets include the riverside Tinapa Resorts with its water parks and Obudu Ranch Resort with its mountain cable cars. Much of Cross River also has a tropical climate and protected jungle conservation areas that nature lovers of all ages can enjoy exploring, the cultural heritage sites include Ikom Monoliths, the Slave History Museum and the National Museum Old Residency, the natural landmarks of tourists interest include Kwa Falls, Agbokim Waterfalls and the volcanic plug of Boje. These are only a few of the many attractions in Cross River State. Private individuals keyed into the tourism drive by investing in ultra modern hotels, hostels and eateries that take care of the evergrowing numbers of tourist in the peak period of Christmas.

In doing all these, the specific objectives of the Cross River State tourism effort includes;

i. To aggressively pursue tourism development programme through the implementation of the Tourism Master Plan. ii. To position tourism as a catalyst for the development of the state by encouraging tourism development planning in order to make Cross River State a choice destination, with enchanting ecologically sustainable tourism products, reliable infrastructure, and services.

iii. To partner with stakeholders, in order to develop and showcase Cross River State as a safe and secure world class tourist destination (Government of Cross River State, 2007).

Despite these lofty objectives and heavy investments on tourism, one aspect of tourism seems to be neglected or at best given just marginal attention. This is the marketing of destination facilities and information.

This study is therefore aimed at showcasing information relating to destination facilities. Some of the details in this study may help tourists in planning their visits and making it a very interesting time out.

\section{LITERATURE REVIEW}

The term tourism, according to Nickerson (1996), is the action and activities of people taking trips to a place or places outside of their home community for any purpose except daily commuting to and from work. Nickerson (1996) believes the term tourism now includes business as well as travel for pleasure. Gee and Fayo-Sola (1997) defined tourism as the activities of persons travelling to and staying in places outside their usual environment for not more than one consecutive year to leisure, business and other purposes.

\section{Reasons for Encouraging Tourism}

Gamble (1989) who wrote on tourism and development in Africa, listed the reasons why African countries need to go into tourism. Some of the reasons given by the author are as follows:

1. World Bank Report of 1969 stated that international tourisms provides for many (developing countries) a useful element in diversifying their sources of foreign exchange earnings and improving the balance of payments;

ii. Creating employment; 
iii. Dispersal of development to nonindustrial areas through the multiplier effect;

iv. Tourism fosters a better understanding among people everywhere and leads to better prospects of peace;

v. Tourism serves as a bridge between nations, leading to a better understanding and tolerance of different cultures and ideologies.

vi. It shows people in the developing countries the material wealth, values and consumers preference of the inhabitants of the developed world.

vii. It projects favourable image of little known or supposedly misunderstood countries.

viii. It encourages people to take pride in their national heritage.

\section{Destination Attractions, Facilities and Services}

Destination attractions, according to Wikipedia (2013) are places where tourists visit, typically for their inherent or exhibited cultural values, historical significance, natural or built beauty or amusement opportunities. Some examples of destination attraction cited by Wikipedia (2013) include historical places, monuments, zoos, aquaria, museums art galleries, botanical gardens, buildings and structures (eg) former prisons, skyscrapers, bridges, national parks and forest, carnivals, living museums, ethnic enclaves, communities and cultural events. Many destination attractions are also landmarks.

Middleton (1988) defined destination facilities and services as elements within the destination, or linked to it, which make it possible for tourists to stay and in other ways enjoy and participate in the attractions. The writer listed them to include:

i. Accommodation units: these include hotels, apartments, villas, campsites, caravan parks etc.

ii. Restaurants, bars and cafes.

iii. Transportation: including taxis, coaches, car rentals, cycle hire.

iv. Sports activity ski schools, sailing schools, golf clubs.

v. Rental outlets- shops, travel agents, souvenir shops and camp supplies. vi. Other services include hairdressing, barbing saloons, information services and tourist guide.

For Gee and Fayo-Sola (1997), tourist services could be grouped into: accommodation, food and beverages, and support services. They observed that accommodation or lodging facilities and their related services are where tourists stay overnight during their travels. They reported that accommodation and related services account for a good portion of the tourists' total expenditure, depending on the quality of the accommodation, destination and purpose of the trip. According to the authors, there are a wide variety of types of accommodations which meet the demands of various budgets including bed and breakfast establishment, European style pensions (school hostels) youth hostels, campgrounds, recreational vehicle parks and cruise ships. The hotels, the most common type of accommodation has its own categories, extending from luxurious urban or resort properties, to small budget oriented motels.

Gee and Fayo-Sola (1997) also reported that food and beverages places include restaurants, bars and other types of eating and drinking outlets, ranging in size and services from stand-alone operations, to units located within a hotel, to small food carts or stalls in a street market. The support services, according to the authors include shopping facilities and services at the destination which help fulfill the basic as well as supplementary needs of visitors. Stories which meet the varying demands of visitors include souvenir shops, duty free shops, laundry services, grocery and departmental stores. Other support services mentioned by the authors include tour guide services, sports and recreation, retail and rental shops, as well as entertainment facilities.

All these services not only make the travel experience more accessible, but fulfill basic needs in addition to the special extras which make the experience more enjoyable. An added benefit is that most of these services demanded provide local jobs and opportunities for local entrepreneurship which help in a way keep the multiplier effect within the country.

\section{International Tourist Impressions about Nigeria}

Oguntoyibo, Areola and Filani (1978) in their article on domestic and international 
tourists, gave the impressions of international tourists about Nigeria. Though it looks as if it is a long time ago, but the tourists' views have not changed much. These impressions could be summarized as follows:

i. The infrastructural facilities for tourism are inadequate.

ii. Some Staff of travel agencies are uncooperating, lukewarm and sometimes incompetent in performance.

iii. Charges are prohibitively excessive for paltry tourism facilities and services.

iv. Most tourist operators have swindling and quick-grabbing propensities.

v. There is indifference and unwelcoming attitude of most workers connected to tourism.

vi. There is a general treatment of tourists as carefree and reckless gamblers who do not mind parting with their money.

Oguntoyibo, et al (1978) quickly countered the findings by observing that these views were unrepresentative of a country whose inhabitants are reputedly hospitable and friendly to a fault.

\section{Challenges to Tourism Development in Nigeria}

The Transport -Aviation and Tourism Information Handbook (1988) reported that over the years, steps have been taken by the Nigerian government to improve development in the tourism sector. Such efforts notwithstanding, certain barriers or constraints have been militating against tourism development in Nigeria. They include:

i. Lack of awareness on the part of individuals and government.

ii. Inadequate financing iii. Lack of infrastructure especially power and good roads.

iv. Insecurity, (especially with the bombing campaigns of Boko Haram in the north, the kidnapping galore of the South militancy in the Niger Delta and the robbery and ritual killings in the South West). All these deter tourists from the country.

\section{METHODOLOGY OF RESEARCH}

This study employed the survey method to investigate the marketing of tourism information in Cross River State. The target population included the tourism services operators and tourists. A self-opinion tourism questionnaire was used in the study. The sample size was sixty nine (69). For ease of administration of questionnaire, three (3) hotels frequently patronized by both domestic and international tourists in Calabar were chosen. The convenience sampling technique was used to distribute the questionnaire to both staff and tourists. Out of the 69 questionnaire copies, 50 useable ones were used in the analysis. The research statistics used in the analyses is the simple percentage for ease of understanding by the anticipated readers.

\section{DATA ANALYSES}

The results obtained from the analyses are presented as follows:

The bio data obtained shows that $33(66 \%)$ of the respondents were aged between sixteen and thirty five years. In terms of gender, there were $32(64 \%)$ males and $18(36 \%)$ females. The result also shows that $27(54 \%)$ of the respondents were first degree holders. This was the largest educational group. 
SECTION B

Tourism Information

Table 1: Tourists Origins

\begin{tabular}{|l|l|l|}
\hline \multicolumn{1}{|c|}{ Tourists Origin } & Frqy & $\%$ \\
\hline Cross River & 12 & 24 \\
\hline South-South & 13 & 26 \\
\hline South-East & 11 & 22 \\
\hline Other parts of Nigeria & 7 & 14 \\
\hline African countries & 4 & 8 \\
\hline Overseas & 3 & 6 \\
\hline
\end{tabular}

The result on Table 2 shows that a majority of tourists in Calabar are drawn from within the state, $(12,24 \%)$, South-South $(13,26 \%)$ and the South-East (32\%).

Table 2: The Most Attractive Tourist Sites/Events

\begin{tabular}{|l|l|l|l|}
\hline S/N & \multicolumn{1}{|c|}{ Tourist Site/Events } & Frqy & \multicolumn{1}{c|}{} \\
\hline 1. & Christmas festival & 46 & 92 \\
\hline 2. & Marina Resort (Water Front) & 30 & 62 \\
\hline 3. & Obudu Mountain Resort & 35 & 70 \\
\hline 4. & Buanchor Canopy Walkway & 14 & 28 \\
\hline 5. & Drill Ranch & 22 & 44 \\
\hline 6. & Nkarasi (Ikom) Monoliths & 18 & 36 \\
\hline 7. & Agbokim waterfall & 23 & 46 \\
\hline 8. & Kwa Falls & 20 & 40 \\
\hline 9. & Tinapa Holiday/Business Resort & 37 & 74 \\
\hline 10. & Obudu Mountain Race & 41 & 82 \\
\hline 11. & Leboku New Yam Festivals & 28 & 56 \\
\hline
\end{tabular}

Table 2 shows that the most attractive tourist sites/events in Cross River include Christmas Festivals (46, 92\%), Obudu Mountain Race (41,82\%), Tinapa Holiday/Business Resort (37,
$74 \%)$, Obudu Mountain Resort (35, 70\%), and Marina Resort (Water front). The percentages indicate the total number of respondents who showed interest in the tourist sites/events. 
Table 3: Most Preferred Tourist Accommodations in Cross River State

\begin{tabular}{|l|l|l|l|}
\hline S/N & Tourist Accommodation & Frqy & $\%$ \\
\hline 1. & Single bedrooms & 24 & 48 \\
\hline 2. & Double bedroom & 15 & 30 \\
\hline 3. & Hostel type accommodation & 7 & 14 \\
\hline 4. & Camp sites & 4 & 8 \\
\hline & Total & 50 & 100 \\
\hline
\end{tabular}

The result on table 3 shows that single bedrooms $(24,48 \%)$ and double bedrooms are the most

preferred tourist accommodations in Cross River State.

Table 4: Most Preferred Tourist Means of Transportation

\begin{tabular}{|l|l|l|l|}
\hline S/N & \multicolumn{1}{|c|}{ Means of transportation } & Frqy & \% \\
\hline 1. & Chartered taxis & 38 & 62 \\
\hline 2. & Car hire services & 29 & 58 \\
\hline 3. & Public mass transit & 51 & 82 \\
\hline 4. & Air crafts & 10 & 20 \\
\hline
\end{tabular}

The result on table 4 shows the most important means of transportation used by tourists in Cross River State include public mass transit, chartered taxis, and car hire services, in that order. Aircrafts are least used by tourists.

Table 5: Sources of Tourist Information About Cross River State

\begin{tabular}{|l|l|l|l|}
\hline S/N & \multicolumn{1}{|c|}{ Information source } & \multicolumn{1}{|c|}{ Frqy } & \multicolumn{1}{c|}{$\%$} \\
\hline 1. & Libraries & 3 & 6 \\
\hline 2. & Tourist guide books & 35 & 70 \\
\hline 3. & Tourist Bureau & 30 & 60 \\
\hline 4. & Radio & 12 & 24 \\
\hline 5. & Television & 12 & 24 \\
\hline 6. & Internet & 32 & 64 \\
\hline 7. & The public & 10 & 20 \\
\hline
\end{tabular}

Table 5 shows source of information for intending and actual tourists in Cross River State. The main source include: tourist guide books (35, $70 \%)$, internet $(32,64 \%)$ and tourism bureau $(30$,
$60 \%$ ). Libraries, radios, television and the public are lesser sources of tourist information in the state. 
Table 6: Most referred Tourist Souvenirs in Cross River State

\begin{tabular}{|l|l|l|l|}
\hline S/N & \multicolumn{1}{|c|}{ Preferred tourist souvenirs } & Frqy & \% \\
\hline 1. & Indigenous art work & 39 & 78 \\
\hline 2. & Indigenous textile materials & 35 & 50 \\
\hline 3. & Indigenous utilities & 27 & 54 \\
\hline 4. & Local artefacts & 8 & 16 \\
\hline
\end{tabular}

Table 6 shows tourist souvenir preference in Cross River State. From the table, it is seen that indigenous arts work is highly valued by tourists. This is followed by indigenous utilities like crayfish by tourists, agricultural products, second hand clothes, cement and so on; and indigenous textiles like print materials.

Table 7: Frequent Complaints of Tourists to Cross River State

\begin{tabular}{|l|l|l|l|}
\hline S/N & \multicolumn{1}{|c|}{ Complaints } & Frqy & \multicolumn{1}{c|}{$\%$} \\
\hline 1. & The food is poor & 3 & 6 \\
\hline 2. & The roads are bad & 41 & 82 \\
\hline 3. & The people are rude and hostile & 1 & 1 \\
\hline 4. & The accommodation are substandard & 4 & 8 \\
\hline 5. & Services are expensive & 18 & 36 \\
\hline
\end{tabular}

Table 7 shows that the frequent complaints of tourists in Cross River is that the roads are bad
$(41,82 \%)$. Another significant complaints is that services are expensive.

Table 8: Frequent Tourist Complementary Remarks in Cross River State

\begin{tabular}{|l|l|l|l|}
\hline $\mathbf{S} / \mathbf{N}$ & \multicolumn{1}{|c|}{ Complementary remarks } & Frqy & \multicolumn{1}{|c|}{$\%$} \\
\hline 1. & The people are very friendly & 35 & 70 \\
\hline 2. & The state is very peaceful & 34 & 68 \\
\hline 3. & Prices are very good & 4 & 8 \\
\hline 4. & The food is wonderful & 28 & 56 \\
\hline 5. & The state is very clean and beautiful & 47 & 94 \\
\hline 6. & The state is worth visiting again & 26 & 52 \\
\hline
\end{tabular}

Table 8 shows the complementary remarks made by tourists visiting Cross River State. It shows that the most frequent remarks was that the state is very clean and beautiful $(47,94 \%)$ other very significant complementary remarks include: the people are friendly $(35,70 \%)$, the state is very peaceful $(34,68 \%)$; the food is wonderful $(28,56 \%)$ and the state is worth visiting again $(26,56 \%)$.

\section{DISCUSSION OF FINDINGS}

The results of the study revealed many interesting findings. In terms of tourist origins, it was found out that many tourists to Cross River State are domestic tourists, coming mainly from other parts of South-South Zone of Nigeria, especially Akwa Ibom, Rivers and Bayelsa. Other domestic tourists come from the South Eastern 
States. Others come from other parts of Nigeria who visit Cross River for conferences, seminars and workshops. Tourists from other parts of Africa and beyond make up $14 \%$. However, during the Christmas festivals, the researchers were told, the percentage of tourists from other parts of Africa and beyond increases to up to $35 \%$.

The results also showed that the Christmas Festival, Obudu Mountain Race, Tinapa Holiday/Business Resort and Obudu Mountain Resort, in that order are the most attractive events/sites. Other events/sites that attract many tourists included Marina Resort (water front), Leboku New Yam Festival, Drill Ranch and Agbokim Waterfall.

In terms of accommodation, single bedrooms and double hotel bedrooms are the most popular types of tourist accommodations.

\section{RECOMMENDATIONS}

Based on the findings of this study, the following recommendations are made to help the government and private operators of tourism in improving their services and attracting both domestic and international tourists;

1. Using multimedia means to reach out to potential tourists.

2. Routes to all tourist sites should be motorable.

3. Carnivals should be spread to all major towns of the state.

4. Provision should be made for a feedback system to get the views of tourists.

5. Train and retrain the staff working in the tourism industry especially those in the hospitality industry and tour guides.

6. Improve on friendliness and first impression because one cannot make a second good impression.

7. There should be more literature on tourism sites and people around them.

8. Reduce taxes on hospitality industries for the services to be affordable to all.

\section{REFERENCES}

Cross River State Government., 2010. Tourism (n.pp

Gamble, W. P., 1992. Tourism and Development in Africa, London: John Murray.

Gee, C. Y and Fayo-Sola, E., 1997. International Tourism: A Global perspective. Madrid: World Tourism Organization.

Middleton, Victor T. C., 1988. Marketing in Travel and Tourism. Oxford: Heinemann Professional.

Nickerson, N. P., 1996. Foundations of Tourism. New Jessey: Prentice-Hall.

Nigeria: Transport-Aviation and Tourism Information Handbook, Directory and Who's Who 1988. Edited by Law C. Fejokwu. Lagos: Media Research Analysts.

Ojo, G. I. Afolabi., 1978. Recreation and Tourism: Patterns and Trends. InOguntoyibo, J. S. Areola, O. O. and Filani, M. (Eds.): A Geography of Nigeria Development, Ibadan: HEB.

Online Etymological Dictionary 2013. http://www.etymonline.com.

Wikipedia 2009. Tourism. URL Address:http://en.wikipedia.org/wiki/Touri sm. Access 10/2/2013. 